\title{
Society pages
}

\section{Officers and Council Members of ffPS}

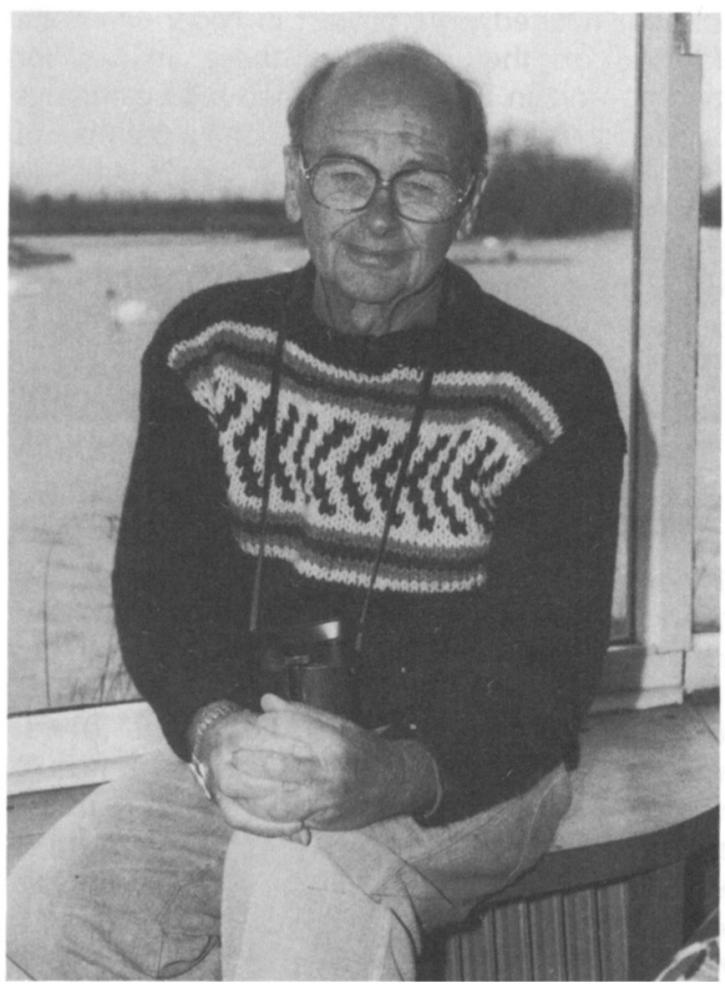

Sir Peter Scott (Philippa Scott).

\section{Sir Peter Scott-ffPS President}

Sir Peter Scott, ffPS President since 1982, has played an active part throughout his life in the conservation of the natural environment by taking practical steps to prevent the extinction of species and to protect natural areas, by increasing public awareness through writing, through the medium of radio and television, and by working tirelessly in a voluntary capacity for a number of international non-governmental organisations, some of which - notably the Wildfowl Trust and the World Wildlife Fund-he was instrumental in creating. In 1956 Sir Peter joined the Executive Board of the IUCN and in 1963 became Chairman of its Survival Service Commission (now Species Survival Commission), a post which he held until 1981. As such he invented and created the Red Data Books. His interests extend across a wide range of environmental problems, from species to ecosystems, from wetlands to tropical Society pages rain forests, from marine pollution and the overexploitation of whales, to human over-population. By profession Sir Peter is an artist who specialises in wildlife painting. He was also trained as a biologist and is a general naturalist with a particular interest in birds and coral reef fishes. He is the author of 16 books and has illustrated 20 others. He was knighted by Her Majesty Queen Elizabeth II in 1973, ' for services to conservation and the environment'.

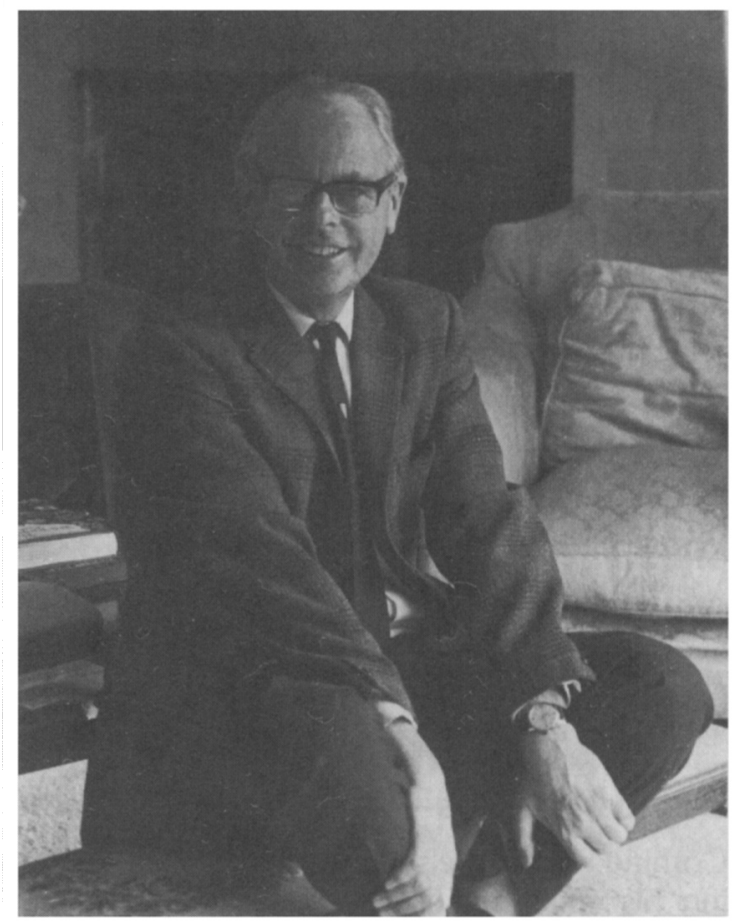

Richard Fitter (Leslie Wesson).

\section{Richard Fitter-ffPS Chairman}

Richard Fitter, Chairman of ffPS Council, cannot remember the time when he was not interested in wildlife so his fascination with the subject must have begun very early. He began his career in wildlife as secretary of his school natural history society and throughout his life has been involved at council or committee level with numerous natural history and conservation bodies, both local and national. He served as Secretary on the 
Wildlife Conservation Special Committee on the Hobhouse Committee on National Parks in 1945-46, whose recommendations were instrumental in setting up Britain's Nature Conservancy (now NCC). He became Honorary Secretary of ffPS in 1964, Vice-Chairman in 1981 and Chairman in 1983. He is currently also Chairman of the Steering Committee of the Species Survival Commission of IUCN and is a Member of the Order of the Golden Ark, presented by Prince Bernhard of the Netherlands for services to conservation. He was successively Honorary Secretary, Chairman and President of the Berkshire, Buckinghamshire and Oxfordshire Naturalists Trust, of which he was a founder. He has written more than 25 books and contributed to 12 others, all on some aspect of natural history or conservation. He married Maisie Stewart Park in 1938 and his recreational activities include botanising, observing wild and human life and exploring new habitats.

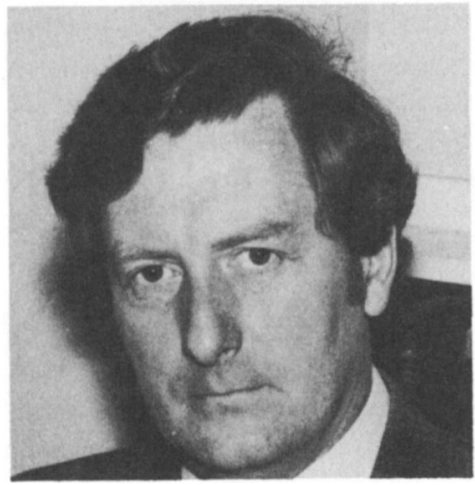

David M. Jones-ffPS Vice-Chairman

Coming from a Welsh farming family and spending his childhood in the countryside of North Wales and Buckinghamshire, where his father was priest of a country parish, both conspired to give David Jones an early interest in wildlife. After qualifying as a veterinarian at the London Veterinary College and also gaining a degree in zoology, specialising in animal physiology, he was appointed as Whipsnade Zoo's first full-time veterinary officer in 1968. The long association between the Zoological Society of London, which is responsible for Whipsnade and London Zoos, and the Brooke Hospital for Animals in Cairo arose from David being invited to Cairo to give advice on the capture of wild animals using darting techniques. 186
He subsequently became involved in many Brooke Hospital projects, the first being the scimitar-horned oryx project in Niger where he advised on the capture of these animals for tagging and in Sri Lanka, when wild elephants needed to be moved. He had been a member of ffPS for some time before he was elected to Council in 1977; in 1980 he was appointed Honorary Secretary and in 1983 Vice-Chairman. $\mathrm{He}$ is now Director of Zoos for the Zoological Society of London.

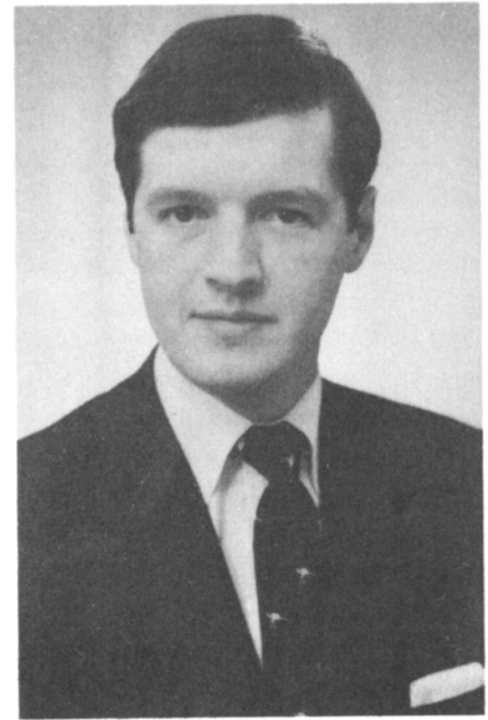

\section{Edward Hoare-ffPS Hon. Treasurer}

Edward Hoare, appointed ffPS Honorary Treasurer in 1983, was born in Wiltshire and his early interest in birds was encouraged by his father. A member of natural history and ornithological societies at school, he took his first holiday alone to the Fair Isle Bird Observatory at the age of 16. After qualifying as a Chartered Accountant in 1977 he spent one year travelling in many countries. It was a memorable wildlife experience, especially in Nepal whose conservation philosophy and practice impressed him, and he returned to the UK determined to use his training in doing something useful for conservation in his spare time. He married Suzie in 1981, who is herself an enthusiastic supporter of wildlife conservation. His main interests are bird watching, travelling, cooking and eating well, gardening, sailing and the use of micro-computers.

Oryx Vol 18 No 3 


\section{Society pages}

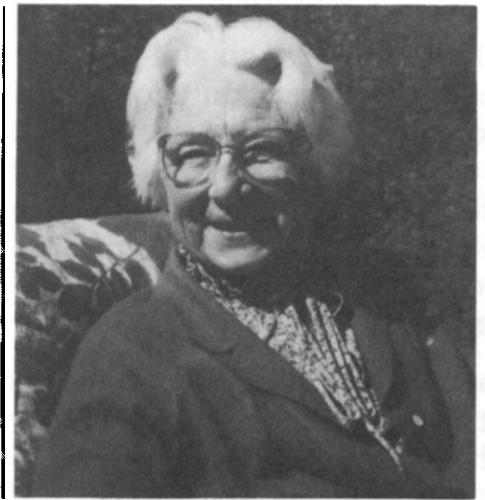

Maisie Fitter

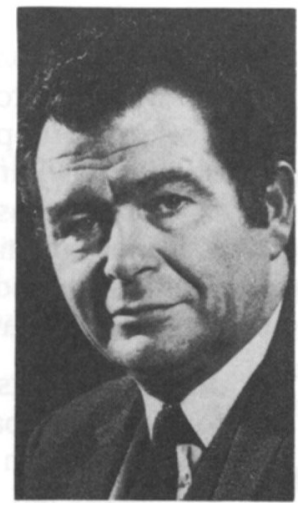

Edward Wright

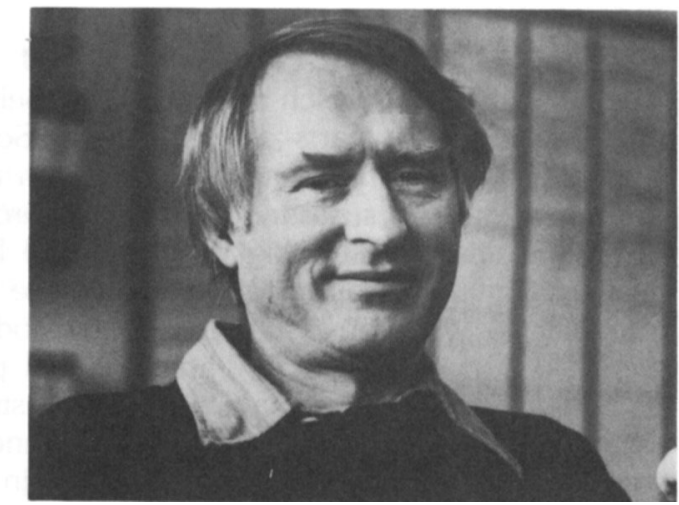

John Sparks

\section{Maisie Fitter-ffPS Council Member}

Maisie Fitter was appointed to the ffPS Council in 1983 on retiring as Honorary Editor of Oryx after 20 years. Her editorial work began when she joined the Editorial staff of The Countryman in 1946, leaving that magazine in 1953. Maisie currently edits the Newsletter of the SSC, having been a member for 15 years. Her interest in conservation led her to become a founder member of the Berkshire, Buckinghamshire and Oxford Naturalists Trust (BBONT), of which she was Chairman in 1975-80 and whose Bulletin she edited for many years. She is currently a member of BBONT's Council and Executive. In 1983 she was made a Member of the Order of the Golden Ark for her services to conservation. Maisie is an enthusiastic gardener with a specialist interest in unusual plants. Her garden in a Chiltern beechwood is visited by badgers and muntjac deer, the latter with an unfortunate taste for the better plants. She is a keen grandmother-of seven.

\section{Edward Wright-ffPS Council Member}

Edward Wright was appointed to the ffPS Council in 1983 and has been interested in wildlife in general since early childhood. He has been closely involved with the British Section of ICBP for many years, firstly as a member of its Publicity Committee and currently of its Finance Committee. He sponsored the now defunct Birds International magazine for its first year and worked Society pages closely with John Burton (the ffPS Executive Secretary), who was then its editor. He considers himself fortunate in living near Battle in Sussex, in gardens and woodlands where wild orchids grow. A colour lithographic printer with works in central London, Edward has, for some years, donated calendars to ffPS and since the launch of the 'new' Oryx in 1983 has donated the colour printing for the front cover.

\section{John Sparks-Member of ffPS Council}

John Sparks, who was elected to ffPS Council in 1983, graduated in zoology at London University, spent five years studying the social behaviour of birds, rodents and monkeys and, after obtaining a Doctorate in animal behaviour, was appointed as a Research Fellow at London Zoo. Since he joined the BBC Natural History Unit in 1965 he has produced nearly 200 radio and 100 television programmes, many focussing on the behavioural aspects of animals. He was one of the producers on 'Life on Earth' and directed the famous sequence where David Attenborough romps with a family of wild mountain gorillas. His work has taken him all over the world, into the waters of the Australian Barrier Reef, to the penguin colonies of Antarctica and to the African savannahs. Apart from scientific papers and numerous popular articles about wildlife, he has written eight books including Owls, The Sexual Connection and The Discovery of Animal Behaviour. He was appointed head of the Natural History Unit in April 1983. 


\section{Bats take off}

\section{Bat workers' seminar, 17-18 March 1984}

The reverence with which bats have been held in the Orient and in parts of Central and South America is a far cry from the superstition and prejudice that has surrounded them in Europe. The difficulties in studying them allowed little encouragement or opportunity to improve this image. But with the development of modern technology a dedicated few amateur and professional workers were able to demonstrate details of the fascinating life-styles of bats and to show that all species were declining. In Britain this led to the protection of two species under the Conservation of Wild Creatures and Wild Plants Act 1975, followed by the protection of all species under the Wildlife and Countryside Act 1981. Bats are also protected in all other European countries. The UK act requires that if any activity is planned that might affect bats or their roosts, the Nature Conservancy Council (NCC) must be consulted to ensure that it is performed in a way and at a time that will cause minimum loss of or disturbance to bats. This applies even to houses and outbuildings and has resulted in the NCC calling upon the help of a national network of volunteers.

With the relevant part of the act having been operative for 18 months and an obvious burgeoning of interest in the study of bats and their protection, the fPPS and the Mammal Society organised a meeting for 17-18 March. In all, well over 300 people attended.

Bob Stebbings (ITE) opened the meeting with an account of the history of bat studies in Britain. The next part of the morning was spent discussing what kind of organisation could best serve the needs of the growing number of county bat groups (the 23rd was inaugurated two days before the meeting) and the many actively interested individuals and organisations, both amateur and professional. It was agreed to form a co-ordinating body to represent the interests of the research side through the Mammal Society (and its bat group) and conservation through the ffPS, whose new full-time bat officer, Tony Hutson, was due to start work on 1 June. Most county bat groups are organised through their county trusts for nature conservation, and these will be represented, as will NCC, ITE and other 188 active bodies, such as WWF. The co-ordinating body will provide support, liaison and guidance for the research and conservation efforts of all workers. People will be encouraged, but not obliged, to join either of the main societies, but they will be asked for a small subscription to a national bulletin. Bat Conservation International (the British end of which is operated by fPS) will also be associated with this organisation.

James Robertson (NCC) outlined the processes for licensing bat workers. NCC has issued over 200 licences in the past 18 months, most of which are restricted to match the experience and requirements of applicants and it is likely that a tiered system, similar to the British Trust for Ornithology's bird-ringing licences, might be introduced to recognise trainers and trainees. Tony Mitchell-Jones (NCC) dealt with the law, placing particular emphasis on the role of NCC and the volunteer advisers who investigate bat complaints. He also reviewed the enquiries that have so far reached the NCC; nearly 180 were received in one week last July and nine species were involved in the course of a year.

The afternoon was devoted to seven short papers on current research, most intended to demonstrate ways in which the new wave of bat workers can contribute to the knowledge of our fauna. Henry Arnold (ITE) showed how poorly recorded is the distribution of our bat species. Tony Hutson (British Museum (Natural History)) discussed the specialist arthropods that live associated with bats and was followed by Russell Gardner (Salford University/ITE) on blood parasites, the possible role of ectoparasites as their vectors and effects they might have on the host. Michael Thompson (Yorkshire Mammal Group) talked about studies at pipistrelle nursery colonies, including age structure and site fidelity. Three papers came from two of the oldest established bat-groups. Michael Clark (Hertfordshire Bat Group) discussed the diverse activities of their small group including research, recording and conservation of their local bats. Clive Banks, from the same group, has tracked down many ice-houses and makes annual counts of the bats that use them as hibernaculae. Phil Richardson (Northants Bat Group), talked on studies of Daubenton's bats including a detailed study of the movements of individual bats after they left the roost.

Oryx Vol 18 No 3 


\section{Society pages}

\section{A legacy for wildlife}

If you wish to leave money to fPS without going to the expense of having your Will professionally re-drawn, we suggest the following form. Follow this carefully and if there appear to be any difficulties raised in relation to what you want to do we suggest you consult a solicitor. Keep the Codicil in a fire-proof place, preferably with your Will and we suggest you keep a separate copy in a different place, perhaps with one of the Executors to ensure that the Codicil is not overlooked.

This Codicil dated

198 is made by me

of

*[formerly of

(insert the address in your original will if different from your present address)

1. I give $£$ to Fauna and Flora Preservation Society, c/o Zoological Society of London, Regent's Park, London NW1 4RY *[for its $100 \%$ Fund] and the receipt of the Treasurer or other proper officer of the Society shall be a complete discharge to my executors.

2. If at my death, Fauna and Flora Preservation Society has ceased to exist or has amalgamated with another Charity or has changed its name, the legacy in Clause 1 shall not fail but my executors shall pay it to the charitable organisation which most nearly fulfils the objects that I intend to benefit.

3. In all other respects I confirm my Will dated

(insert date of original Will)

Signed by the Testator/Testatrix $\mathrm{X}$

in our joint presence and

witnessed by us in his/hers

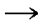

*Delete as appropriate.
(The testator should sign where there is a cross on the sample.)

Two witnesses who should watch the testator sign should then sign their own names address and occupations where shown by arrows in the example 


\section{Gifts and Grants to ffPS}

ffPS is most grateful for the gifts of 125 and over listed below and also for many smaller donations between 1 January and 31 March 1984.

Oryx $100 \%$ Fund

W.D. Francis

S.K. Sharma

J. Stewart Smith

P. Sugden

P.J. Belman

Anon.

D. Mcllraith

J. Grainger

Anon.

Mountain Gorilla Project

J. Poole

S. Blamire

S.M. Cooper

J. Russell

R.N. Hill

E.M. Portelly

Bat Projects

Young People's Trust for Endangered Species

R.E. Stebbings

Capt. Sir John Leslie

H.R. Arnold

P.M. Russell

A.M. Hutson/TV South

Orchid Project

J.P.C. Nohl-Oser

250.00

General Fund

Consolidated Gold Fields

A. Hutchinson

Zoological Society of London

I. Strange

R.K. Backman

$10,000.00$

350.00

250.00

62.00

50.00

\section{Legacy}

Estate of Noel Wooding

In memory of the late J.E.M. Mellor

(donations from family and friends)

\section{Oryx 100\% Fund Grants}

At its meeting on 10 January 1984 the ffPS Council approved a grant of:

$£ \mathbf{5 0 0}$ to Dr Kes Hillman (IUCN/Parc National de la Garamba, c/o BAT Dept Agricole, BP 621, Kinshasa 1, Zaire) for her preliminary survey of the white rhino population in the Garamba National Park, Zaire, to find out its status and assess the feasibility of proposed plans for its protection.

At its meeting on 12 April 1984 the fPSS Council approved the following grants:

$£ 1600$ to lan Grimwood for the purchase of six radio collars and a receiver to help monitor the white rhino population in Zaire.

$£ 1600$ for a patrol boat for an ICBP reserve in Cousin Island, Seychelles. The aluminium boat is needed for supplies, to ferry visitors, and to patrol the coast to guard against poachers. It will replace the present wooden boat, which is heavy and needs constant maintenance.

$£ 500$ to J.A.A. Gomes (Universidade do Rio Grande, Laboratorio de Communidades Nectonicas, C. Postal 474-96200, Rio Grande-RS-Brazil) for his study of the effects of incidental catches on the population of La Plata dolphin. Results, including details of the fishing industry involved, will be sent to the Federal Fisheries so that steps can be taken to regulate to prevent further incidental catches. Operating dates: April-December 1984.

$£ 500$ to Jana Stirton (c/o Royal Botanic Gardens, Kew, Richmond, Surrey) to attend the 11th World Orchid Conference in Miami, Florida, USA in March 1984. This will help her ffPS-funded project to establish a register of traders and nurseries of orchids.

$\mathbf{\$ 4 0 0}$ to Euan K. Dunn (Edward Grey Institute, Department of Zoology, South Parks Road, Oxford OX1 3PS) for his status study of the roseate tern in the Azores. The Azores is now the only site where no

Oryx Vol 18 No 3 


\section{Society pages}

accurate data on this species have been collected. Operating dates: 1 June-midJuly 1984.

$£ \mathbf{3 0 0}$ to Gary Allport (17 Harford Manor, Ipswich Road, Norwich, Norfolk) for his Indonesian Waterbird Survey with the University of East Anglia. Intensive rice cultivation and hunting pressures are forcing bird populations in the mangrove swamps in north-west Java to decline. Results of the survey and conservation proposals will be sent to the relevant authorities in Indonesia. Operating dates: mid-July to end September 1984.

$£ 250$ to Dr J.R. Flenley (Department of Geography, The University, Hull HU6 7RX) for his study of the Moorea tree snail; the destruction of its habitat (tropical rain forest) and predation by an introduced species of snail have caused its decrease in numbers. Results will help in the formulation of conservation measures. Operating dates: 7 July to mid-August 1984.

$£ 200$ to Geoff Welch (2 Springholme, Caudle Hill, Fairburn, Knottingley, W. Yorkshire WF11 9JQ) for his status study of birds in Djibouti. Results will be sent to the Djibouti authorities and ICBP to help in follow-up conservation plans. Operating dates: 11 March-6 April 1984.

$\mathfrak{£ 2 0 0}$ to the Yorkshire Wildlife Trust (20 Castlegate, York YO1 1RP) towards the cost of wardening for three years at Salt Lake Quarry. This is one of the few UK sites of the coral-root orchid. Visitor pressure has been causing severe damage to this and other rare species of plant. A warden during late spring and summer would direct visitors to one supervised and selected spot.

\section{Mountain Gorilla report}

Due to circumstances beyond our control, the detailed report of the Mountain Gorilla Project scheduled for the July issue, will appear in the October issue.

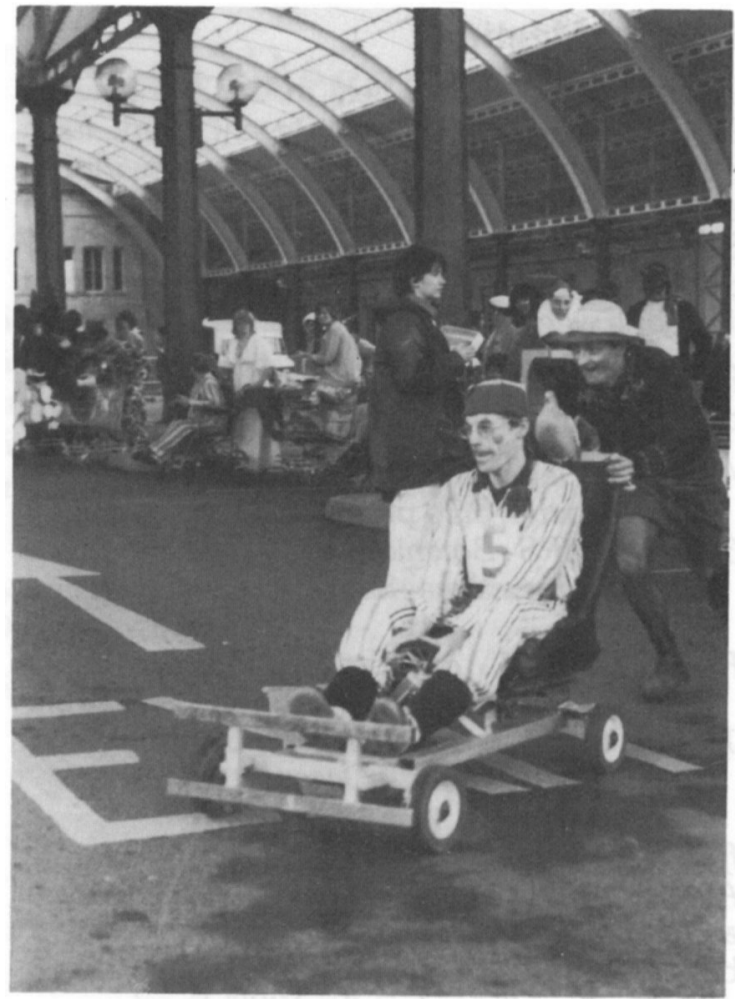

Part of a sponsored pram-push around Bath, UK, organised by a Sainsbury's Branch Manager in aid of the Mountain Gorilla Project.

\section{Sainsbury's staff support MGP}

Sean Whyte, Branch Manager of Sainsbury, Bath, has organised fund-raising events through his and other Sainsbury branches, including a sponsored lunch-time sit-up in the staff canteen that raised $£ 150$, and a pram push round Bath. Over $£ 3000$ has been raised so far.

\section{Mountain Gorilla Project More volunteers wanted}

The Mountain Gorilla Project needs more volunteers to organise sponsored walks, swims, competitions etc and film evenings to raise funds and publicise the project. Material-slide packs, posters, stickers, sponsorship forms, fund-raising ideas and details for example-will be available from the office. 